\title{
BMJ Global Health Diversity in the editorial boards of global health journals
}

\author{
Soumyadeep Bhaumik (D) ,' Jagnoor Jagnoor ${ }^{1,2}$
}

\begin{abstract}
To cite: Bhaumik S, Jagnoor J. Diversity in the editorial boards of global health journals. BMJ Global Health 2019;4:e001909. doi:10.1136/ bmjgh-2019-001909
\end{abstract}

Handling editor Seye Abimbola

- Additional material is published online only. To view please visit the journal online (http://dx.doi.org/10.1136/ bmjgh-2019-001909).

Received 12 August 2019 Revised 26 September 2019 Accepted 28 September 2019

Check for updates

(C) Author(s) (or their employer(s)) 2019. Re-use permitted under CC BY. Published by BMJ.

${ }^{1}$ The George Institute for Global Health, India, New Delhi, India ${ }^{2}$ The George Institute for Global Health, University of New South Wales, Sydney, New South Wales, Australia

Correspondence to Dr Soumyadeep Bhaumik; sbhaumik@georgeinstitute. org.in

\section{INTRODUCTION}

Diversity in global health workforce and leadership has received a lot of attention, particularly in terms of gender and representation of low/middle-income countries in global health institutions like the WHO. ${ }^{1-4}$ Representation of women in medical journals has been studied extensively including for authorship, peer-reviewers and editorial positions in several medical specialities, ${ }^{5-14}$ with only a few studies analysing geographical diversity. ${ }^{15} 16$ Although many journals champion diversity narratives in several domains of global health, ${ }^{17-19}$ the issue of diversity in specialty global health journals has not been studied previously.

Having an editorial role in an academic journal reflects status and indicates leadership and influence within a field. Thus, having diverse editorial boards can help to promote diverse and balanced perspectives, ensure equity and fairness, serve a role modelling function for future generations and enable the decolonisation of global health research evidence and narratives. In addition, a diverse editorial board can also provide access to a wider pool of peer-reviewers and encourage submission from researchers of diverse backgrounds. We therefore sought to understand the diversity in editorial board of specialty global health journals.

We identified 27 specialty global health journals (from the National Library of Medicine, USA catalogue ${ }^{20}$-see online supplementary file for search terms, inclusion criteria and process). We analysed their editorial boards for diversity in 2018. To assign diversity scores, we developed a Composite Editorial Board Diversity Score (CEBDS) which evaluated diversity in three domains: gender, country income-level and geographic region. Scores were assigned in each domain as in table 1 and CEBDS was calculated by adding up all the individual domain scores. Journals were considered
Summary box

We present a new scoring system (Composite Editorial Board Diversity Score (CEBDS)) to evaluate the diversity of editorial board in terms of three parameters-gender, country income-level and geographic region.

- We analysed the diversity of the editorial boards of 27 specialty global health journals - of 303 editors, $40 \%$ were females; $68 \%$ based in high-income countries; $34 \%$ were based in Europe and Central Asia and $30 \%$ were based in North America. And among editors-in-chief, $27 \%$ were females and $73 \%$ were based in high-income countries.

- Only $26 \%$ of journals had the highest possible score in the gender diversity domain $(40 \%-60 \%$ female editors), $11 \%$ had the highest possible score in the country income-level domain (at least one editor in all country income groups) and $7 \%$ had the highest possible score in the geographic region diversity domain (at least one editor in all six regions). Overall, only $11 \%$ of journals had high CEBDS $(\geq 8)$.

- There is need for studies to understand enablers and barriers of diversity in journal editorial boards. Affirmative action and application of organisational good practices for improving diversity, inclusion and belongingness is required to ensure diversity in editorial board of global health journals.

as having poor diversity if CEBDS was $\leq 5$, moderate diversity if CEBDS was 6 or 7 and good diversity if CEBDS was $\geq 8$.

We determined gender (binary), using a sequential approach (ie, by going to the next criterion if the preceding one did not yield enough information): first, editor description on journal website; then a web application, Genderize, ${ }^{21}$ which determines the gender of a first name along with a probabilistic certainty score (accepted only when $\geq 0.95$ ); then editor description on institutional website; and finally, inspection of names by authors (decided by consensus). We also used a sequential approach to identify the country in which editors are based: first, editor descriptions on the journal website; then editor descriptions on institutional website. 


\begin{tabular}{|c|c|c|c|}
\hline $\begin{array}{l}\text { Score } \\
\text { assigned }\end{array}$ & $\begin{array}{l}\text { Gender } \\
\text { diversity } \\
\text { domain (GID) }\end{array}$ & $\begin{array}{l}\text { Country income- } \\
\text { level diversity } \\
\text { domain (CIDD) }\end{array}$ & $\begin{array}{l}\text { Geographic } \\
\text { region diversity } \\
\text { domain (RID) }\end{array}$ \\
\hline 0 & $\begin{array}{l}\text { All male or all } \\
\text { female editors }\end{array}$ & $\begin{array}{l}\text { All editors based } \\
\text { in one World } \\
\text { Bank Income } \\
\text { classification group }\end{array}$ & $\begin{array}{l}\text { All editors based } \\
\text { in one World Bank } \\
\text { Region }\end{array}$ \\
\hline 1 & Not applicable & $\begin{array}{l}\text { At least one editor } \\
\text { based in two of } \\
\text { the four World } \\
\text { Bank Income } \\
\text { classification } \\
\text { groups }\end{array}$ & $\begin{array}{l}\text { At least one editor } \\
\text { based in two or } \\
\text { three of the total } \\
\text { seven World Bank } \\
\text { Regions }\end{array}$ \\
\hline 2 & $\begin{array}{l}1 \%-39 \% \\
\text { female editors }\end{array}$ & $\begin{array}{l}\text { At least one editor } \\
\text { based in three } \\
\text { of the four World } \\
\text { Bank Income } \\
\text { classification } \\
\text { groups }\end{array}$ & $\begin{array}{l}\text { At least one editor } \\
\text { based in four or } \\
\text { five of the total } \\
\text { seven World Bank } \\
\text { Regions }\end{array}$ \\
\hline 3 & Not applicable & $\begin{array}{l}\text { At least one editor } \\
\text { based in all four } \\
\text { World Bank Income } \\
\text { classification } \\
\text { groups }\end{array}$ & $\begin{array}{l}\text { At least one editor } \\
\text { based in six of the } \\
\text { total seven World } \\
\text { Bank Regions }\end{array}$ \\
\hline 4 & $\begin{array}{l}40 \%- \\
60 \% \text { female } \\
\text { editors }\end{array}$ & Not applicable & Not applicable \\
\hline $\begin{array}{l}\text { CEBDS } \\
\text { calculation }\end{array}$ & $\begin{array}{l}\text { GID + CIDD - } \\
10)\end{array}$ & ID (minimum scor & maximum score \\
\hline
\end{tabular}

CEBDS, Composite Editorial Board Diversity Score.

For gender and country, if none of the steps led to an inference, we marked the category as unclear for the editor.

We grouped countries using the World Bank Classification $^{22}$ to categorise by region (seven groups: East Asia and Pacific, Europe and Central Asia, Latin America and the Caribbean, Middle East and North Africa, North America, South Asia and Sub-Saharan Africa) and income status (four groups: low-income, lower-middle-income, upper-middle-income and high-income economies).

\section{DIVERSITY IN EDITORIAL BOARDS OF GLOBAL HEALTH JOURNALS}

All but one of the 27 journals are published in high-income countries-that is, Clinical Epidemiology and Global Health, published in India. Of the 303 editors listed on the websites of the 27 journals, there were 122 female $(40 \%)$ and 168 male $(56 \%)$ editors; and the gender of $13(4 \%)$ editors could not be determined based on the available information. However, only 10 out of 37 (27\%) editors-in-chief were females. Most managing editors were females (78\%-ie, 14 out of 18$)$. Among female editors most were associate editors $(57 \%$-ie, 70 out of 122 ), but women were only $39 \%$ of associate editors (70 out of 181)

The country of location was not clear for 23 editors $(8 \%)$. But the majority of editors are based in high-income countries (68\%, n=206). Among editors-in-chief, $73 \%$ (27 out of 37), are based in high-income countries and none in low-income countries and only one journal had an editor based in a lower middle-income country. Regionally, 30\% ( $\mathrm{n}=91)$ of editors are based in the North America, 34\% ( $\mathrm{n}=102)$ based in Europe and Central Asia and only $2 \%(n=6)$ based in the Latin America and Caribbean region. The distribution of editors-in-chief across different regions was similar, but there were no editors-inchief based in the Latin America and Caribbean region (see online supplementary file for detailed information on individual domains and editorial position subtypes).

The scorings for individual domains, as well as the overall CEBDSs are presented in figure 1. The highest possible diversity score for individual CEBDS domains was achieved in only three journals; and none got the highest possible score in all the three domains. Only seven journals had the highest score in the gender diversity domain, three had the highest score in the country income-level domain and two had the highest score in the geographic region diversity domain. Five journals got the lowest possible score of 0 indicating no diversity in their editorial boards.

We did not consider the existence of other gender identities (beyond the male-female binary) and acknowledge small possibilities of individual gender misclassification. However, we contend that these limitations are not likely to influence our findings. We developed the CEBDS as an objective measure of diversity for use on publicly available data-to allow comparison between journals and monitor progress over time without survey data from individual journal editors. It is important to understand diversity from a broader perspective including characteristics such as skin colour, class, socioeconomic status, sexual preferences, profession as well as social networks, especially of editors from low and middle income country (LMIC) . However, such data are difficult to compile and may not be suitable for rapid scans or comparison across journals which CEBDS allows.

\section{CONCLUSION}

Many global health actors are working to improve women representation in leadership positions, including at the United Nations and its agencies. ${ }^{5} 172324$ But, as our findings indicate, the need for diversity in global health is not limited to gender. We noticed a 'glass ceiling, ${ }^{25}$ effect for all three parameters-gender, geography and country income-level. The glass ceiling effect was such that, barring few exceptions, editors-in-chief are males based in high-income European or North American countries.

Existing studies show that key factors limiting the role of women in leadership positions are organisational gendering process and social barriers due to gender roles. ${ }^{23}$ But not much is known about barriers to having journal editors based in underrepresented regions of the world, and from low/middle-income countries. Academics in these settings may face unique challenges. 


\begin{tabular}{|r|l|c|c|c|c|}
\hline SI. & \multicolumn{1}{|c|}{ Name of Journal } & $\begin{array}{c}\text { Gender } \\
\text { Diversity }\end{array}$ & $\begin{array}{c}\text { Geographic } \\
\text { Region Diversity }\end{array}$ & $\begin{array}{c}\text { Country } \\
\text { Income-Level } \\
\text { Diversity }\end{array}$ & CEBDS \\
\hline 1 & Annals of Global Health & 2 & 0 & 0 & 2 \\
\hline 2 & BMC International Health and Human Rights & 4 & 1 & 2 & 7 \\
\hline 3 & BMJ Global Health & 2 & 2 & 3 & 7 \\
\hline 4 & Central Asian Journal of Global Health & 2 & 0 & 0 & 2 \\
\hline 5 & linical Epidemiology and Global Health & 2 & 0 & 0 & 2 \\
\hline 7 & Global Health Action & 2 & 1 & 1 & 4 \\
\hline 8 & Global Health Communication & 4 & 0 & 1 & 5 \\
\hline 9 & Global Health Governance & 2 & 0 & 0 & 2 \\
\hline 10 & Global Health Research and Policy & 4 & 1 & 1 & 6 \\
\hline 11 & Global Health, Science and Practice & 2 & 1 & 1 & 4 \\
\hline 12 & Global Journal of Health Science & 4 & 0 & 0 & 4 \\
\hline 13 & Global Mental Health & 4 & 0 & 1 & 3 \\
\hline 14 & Global Pediatric Health & 2 & 1 & 1 & 6 \\
\hline 15 & Global Public Health & 4 & 0 & 0 & 2 \\
\hline 16 & Globalization and Health & 4 & 2 & 2 & 7 \\
\hline 17 & International Health & 0 & 0 & 2 & 8 \\
\hline 18 & International Public Health Journal & 0 & 0 & 0 & 0 \\
\hline 19 & Journal of Epidemiology and Global Health & 2 & 1 & 1 & 1 \\
\hline 20 & Journal of Global Health & 2 & 3 & 1 & 4 \\
\hline 21 & Journal of Global Health Perspectives & 0 & 0 & 3 & 8 \\
\hline 22 & Medicine, Conflict, and Survival & 2 & 0 & 0 & 0 \\
\hline 23 & Pathogens and Global Health & 0 & 0 & 0 & 3 \\
\hline 24 & Pediatrics and International Child Health & 2 & 1 & 1 & 0 \\
\hline 25 & The Lancet Global Health & 0 & 0 & 0 & 4 \\
\hline 26 & The Lancet Planetary Health & 0 & 0 & 0 & 0 \\
\hline 27 & Tropical Medicine and International Health & 2 & 3 & 3 & 8 \\
\hline
\end{tabular}

Figure 1 Diversity scores of specialty global health journals. CEBDS, Composite Editorial Board Diversity Score.

Clearly, global health journals can do much better on diversity in their editorial boards, and should adopt affirmative action policies and organisational good practices on diversity, inclusiveness and belongingness. ${ }^{26}$

Contributors SB: conceptualisation, data curation, formal analysis, investigation, methodology, project administration, visualisation, writing—original draft preparation. JJ: validation, writing — review and editing

Funding The authors have not declared a specific grant for this research from any funding agency in the public, commercial or not-for-profit sectors.JJ Is supported by the NHMRC Early Career Fellowship Award.

Editor's note While we recognise that it is only a first step on a long process of de-colonising global health, BMJ Global Health pledges that in the next two years, we will achieve parity in representation (between people based in low- and middle-income countries and those in high-income countries; and between men and women) on our editorial board.

Competing interests $\mathrm{SB}$ is an associate editor at the BMJ Global Health, which is a journal included in the study and is an analysis advisor of The BMJ. SB declares no other competing interests. JJ declares no conflicts of interests.

Patient consent for publication Not required.

Provenance and peer review Not commissioned; internally peer reviewed.

Data availability statement Relevant summary data of the study has been uploaded as part of supplementary information.

Open access This is an open access article distributed in accordance with the Creative Commons Attribution 4.0 Unported (CC BY 4.0) license, which permits others to copy, redistribute, remix, transform and build upon this work for any purpose, provided the original work is properly cited, a link to the licence is given, and indication of whether changes were made. See: https://creativecommons.org/ licenses/by/4.0/.

ORCID iD

Soumyadeep Bhaumik http://orcid.org/0000-0001-9579-4453

\section{REFERENCES}

1 Talib Z, Burke KS, Barry M. Women leaders in global health. Lancet Glob Health 2017;5:e565-6.
2 Newman C. Time to address gender discrimination and inequality in the health workforce. Hum Resour Health 2014;12:25.

3 Barry M, Talib Z, Jowell A, et al. A new vision for global health leadership. The Lancet 2017;390:2536-7.

4 Downs JA, Reif LK, Hokororo A, et al. Increasing women in leadership in global health. Academic Medicine 2014;89:1103-7.

5 lyer AR. Authorship trends in the Lancet global health. Lancet Glob Health 2018;6:e142.

6 Harris CA, Banerjee T, Cramer M, et al. Editorial (spring) board? gender composition in high-impact general surgery journals over 20 years. Ann Surg 2019;269:582-8.

7 Topaz CM, Sen S. Gender representation on Journal editorial boards in the mathematical sciences. PLoS One 2016;11:e0161357.

8 Fishman M, Williams WA, Goodman DM, et al. Gender differences in the authorship of original research in pediatric journals, 2001-2016. $J$ Pediatr 2017:191:244-9.

9 Piper CL, Scheel JR, Lee Cl, et al. Representation of women on radiology Journal editorial boards: a 40 -year analysis. Acad Radiol 2018;25:1640-5.

10 Cho AH, Johnson SA, Schuman CE, et al. Women are underrepresented on the editorial boards of journals in environmental biology and natural resource management. PeerJ 2014;2:e542.

11 Litvack JR, Wick EH, Whipple ME. Trends in female leadership at high-profile otolaryngology journals, 1997-2017. Laryngoscope 2019;129:2031-5.

12 Williams WA, Garvey KL, Goodman DM, et al. The role of gender in publication in the Journal of pediatrics 2015-2016: equal reviews, unequal opportunities. J Pediatr 2018:200:254-60.

13 Toledo P, Duce L, Adams J, et al. Diversity in the American Society of Anesthesiologists leadership. Anesthesia \& Analgesia 2017;124:1611-6.

14 Bhaumik S, Mathew RJ. Representation of women as editors in the Cochrane collaboration. J Evid Based Med 2014;7:249-51.

15 Mullan Z. Thank you to our diverse (but not diverse enough) reviewers. Lancet Glob Health 2018;6:e1056-7.

16 Sumathipala A, Siribaddana S, Patel V. Under-Representation of developing countries in the research literature: ethical issues arising from a survey of five leading medical journals. BMC Med Ethics 2004;5:E5.

17 Clark J, Horton R. What is the Lancet doing about gender and diversity? The Lancet 2019;393:508-10.

18 Khan MS, Lakha F, Tan MMJ, et al. More talk than action: gender and ethnic diversity in leading public health universities. The Lancet 2019;393:594-600. 
19 Sheikh K, Josyula LK, Zhang X, et al. Governing the mixed health workforce: learning from Asian experiences. BMJ Glob Health 2017;2:e000267

20 National Center for Biotechnology Information. NLM catalog, 2017. Available: https://www.ncbi.nlm.nih.gov/nlmcatalog/

21 Genderize. Determine the gender of a name, 2018. Available: https:// genderize.io/

22 The World Bank Group. World bank country and lending groups, 2018. Available: https://datahelpdesk.worldbank.org/ knowledgebase/articles/906519-world-bank-country-and-lendinggroups
23 Newman C, Chama PK, Mugisha M, et al. Reasons behind current gender imbalances in senior global health roles and the practice and policy changes that can catalyze organizational change. Glob Health Epidemiol Genom 2017;2:e19.

24 Schwalbe N. Global health: generation men. The Lancet 2017;390.

25 Davidson MJ, Cooper CL. Shattering the glass ceiling: the woman manager. London, England: Paul Chapman Publishing, 1992.

26 Gillespie JJ, Dunsire D, Luce CB. Attaining gender parity: diversity 5.0 and 10 best practices for global health care organizations. Health Care Manag 2018;37:195-204. 